\title{
Stratifying triple-negative breast cancer: which definition(s) to use?
}

\author{
Barbara Adamo $0^{1,2}$ and Carey K Anders ${ }^{2,3 *}$ \\ See related research by Keam et al., http://breast-cancer-research.com/content/13/2/R22
}

\begin{abstract}
Triple-negative breast cancers (TNBC) have increased rates of pathologic complete response following neoadjuvant chemotherapy, yet have poorer prognosis compared with non-TNBC. Known as the triplenegative paradox, this highlights the need to dissect the biologic and clinical heterogeneity within TNBC. In the present issue, Keam and colleagues suggest two subgroups of TNBC exist based on the proliferationrelated marker Ki-67, each with differential response and prognosis following neoadjuvant chemotherapy. To place results into context, we review several definitions available under the TNBC umbrella that may stratify TNBC into clinically relevant subgroups.
\end{abstract}

Studies to enhance our understanding of the triplenegative breast cancers (TNBC) spectrum are needed to improve our current management, and ultimately outcomes, of patients diagnosed with TNBC. In the present issue, Keam and colleagues explored the expression of the proliferation-related marker Ki-67 in 105 patients with TNBC treated with neoadjuvant chemotherapy [1]. Their results suggest two subgroups of TNBC might exist by Ki-67 expression, each with differential response and prognosis following neoadjuvant chemotherapy.

TNBC - defined as estrogen receptor, progesterone receptor and human epidermal growth factor receptor type 2 (HER2) negativity - are heterogeneous in terms of biology, prognosis and response to treatment [2-7]. TNBC are associated with younger age at diagnosis [8] and with poorer outcomes compared with non-TNBC [912]. Patients with TNBC, however, have increased rates of pathological complete response ( $\mathrm{pCR}$ ) after neoadjuvant

\footnotetext{
*Correspondence: canders@med.unc.edu

² Lineberger Comprehensive Cancer Center, 170 Manning Drive, CB 7305,

University of North Carolina, Chapel Hill, NC, 27599-7305, USA

Full list of author information is available at the end of the article
}

chemotherapy compared with other subtypes $[9,10]$. The presence or absence of residual disease after preoperative chemotherapy has been found to be a strong predictor of survival in TNBC. Liedtke and colleagues found 3-year survival of TNBC patients with and without residual disease after neoadjuvant chemotherapy to be $68 \%$ and $94 \%$, respectively [10]. The increased pCR rates but worse survival observed in TNBC - the triple-negative paradox [9] - appears to be driven by higher relapse rates among those patients whose tumors are not eradicated by chemotherapy.

Among 105 patients with TNBC treated with neoadjuvant chemotherapy, Keam and colleagues identified 26.7\% TNBC with low Ki-67 (defined as staining in $<10 \%$ of cells) despite most cases being high grade [1]. Secondly, they evaluated the association of Ki-67 with $\mathrm{pCR}$ and survival after only three cycles of preoperative chemotherapy (doxorubicin/docetaxel), which may explain the lower rate of $\mathrm{pCR}(13.3 \%)$ compared with previous studies $[10,13]$. All TNBC patients achieving pCR were identified within the high Ki-67 group (18.2\%), and they showed improved relapse-free survival and overall survival compared with those TNBC patients with residual disease and high Ki-67. Conversely, none of the TNBC patients with low Ki-67 achieved pCR; survival was similar to those with high Ki-67 who achieved pCR.

The data presented herein suggest that two subgroups of TNBC might exist based on Ki-67 with differential response and prognosis after preoperative chemotherapy. More importantly, it seems that only within the high Ki-67 group will pCR possibly be an appropriate surrogate for survival outcome. It is important to point out that TNBC patients with residual disease, even those with low Ki-67, still have 5-year relapse-free survival of roughly $75 \%$. From a clinical perspective, these patients are still at a substantial risk for relapse. Although this study raises important questions, further validation of $\mathrm{Ki}-67$ in independent datasets and optimal cutoff values in TNBC are needed [14].

Previous studies have shown that TNBC are not a single disease process [3-7,15-17]. These studies have used various markers evaluated by different assays based 
on protein expression, gene expression or gene mutation status (Figure 1). Global gene expression studies illustrate two main intrinsic subtypes of breast cancer (basal-like and claudin-low) within TNBC - although the basal-like subtype predominates (50 to 70\%) [4], with high rates of p53 mutations [18]. The recently characterized claudinlow subtype is mostly composed of high-grade invasive ductal carcinomas with a high frequency of metaplastic and medullary differentiation [3,4]. Compared with basal-like tumors, claudin-low tumors are enriched for mesenchymal and stem cell-like biological processes $[3,4]$. Claudin-low tumors show lower expression of proliferation-related genes, including MKI67 [3]. While survival differences have not been observed between the basal-like and claudin-low subtypes, claudin-low tumors showed lower rates of pCR (versus basal-like) after preoperative anthracyline/taxane-based chemotherapy in a cohort of 133 patients [3]. Evidence for other subtypes within TNBC, including mesenchymal-related, proliferation-related and immune-related subsets, with varying prognoses have also been suggested by other investigators [17].

Studies based on basal immunohistochemical markers (epidermal growth factor receptor type 1 (EGFR), cytokeratin 5/6) have shown that at least two subgroups of TNBC exist $[5,6]$. Nielsen and colleagues, using a panel of basal-like tumors (defined by gene expression profiling), observed that four immunohistochemical markers (estrogen receptor-negative, HER2-negative, and/or EGFRpositive or cytokeratin 5/6-positive) could accurately identify basal-like tumors with high specificity [5]. In a subsequent study, Cheang and colleagues observed superior prognostic value of the basal-like immunohistochemical definition (core basal) using these four biomarkers (plus progesterone receptor negativity) than when using the standard estrogen receptor-negative/ progesterone receptor-negative/HER2-negative definition [6]. The other triple-negative group, defined as negativity for all five biomarkers (five-marker negative phenotype), showed improvement in breast cancerspecific survival compared with the core basal group. It is currently unknown whether the five-marker negative phenotype group is associated with the claudin-low tumors and/or the low Ki-67 tumors. Additional studies to determine the relationship between five-marker negative phenotype tumors, claudin-low tumors and low Ki-67 tumors, and possible overlap within TNBC, are certainly worthy of exploration.

The association between BRCA1 mutations and the development of TNBC is well established [16]. A recent report suggests that $B R C A 1$ mutations occur in close to $20 \%$ of sporadic TNBC and are associated with improved prognosis [15]. It is currently unknown whether BRCA1mutated tumors more closely resemble claudin-low or

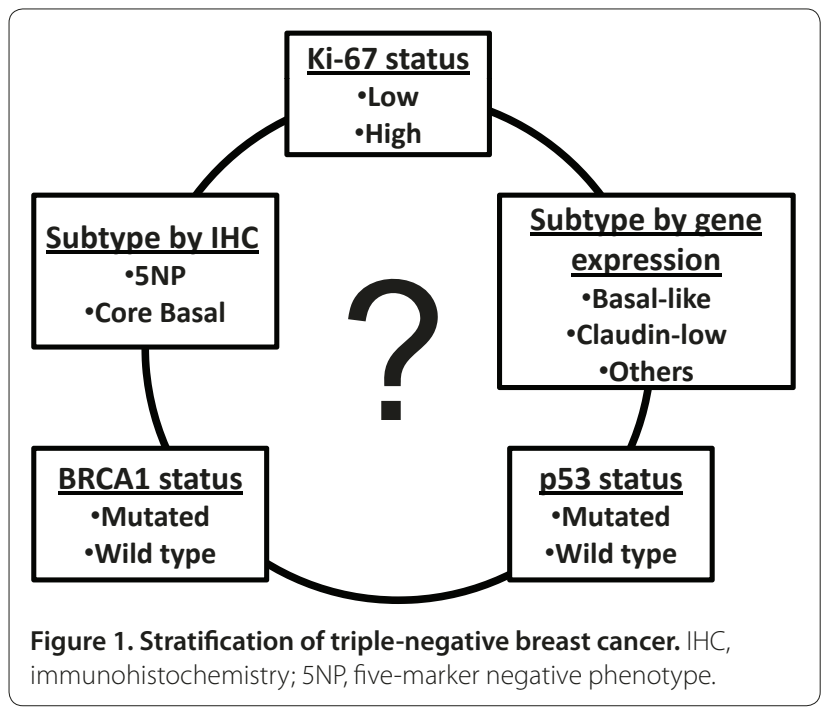

basal-like TNBC. Moreover, tumors arising in BRCA1 mutation carriers illustrate sensitivity to poly-(ADP)ribose polymerase inhibitors, thus suggesting that mutated BRCA1 within TNBC could be predictive of response to this novel class of agents $[19,20]$.

TNBC are heterogeneous and there are probably clinically-relevant subtypes within this subset of breast cancer. A remaining clinical question is which patient post-neoadjuvant chemotherapy requires additional systemic therapy to optimize the outcome? The relationship(s) of the various TNBC subgroups identified by either cytokeratin 5/6-EGFR, Ki-67 or BRCA1 status and molecular subtyping by gene expression to help answer this question certainly warrant further investigation. Coordinating the many definitions under the TNBC umbrella to use each of the available biomarkers, either individually or in combination, to stratify TNBC into clinically relevant subgroups should be our ultimate goal.

\section{Abbreviations}

EGFR, epidermal growth factor receptor type 1; HER2, human epidermal growth factor receptor type 2; pCR, pathological complete response; TNBC, triple-negative breast cancers.

\section{Competing interests}

The authors declare that they have no competing interests.

\section{Author details}

'Department of Human Pathology, Integrated Therapies in Oncology Unit, University of Messina, Via Consolare Valeria N.1 98125 Messina, Italy. ${ }^{2}$ Lineberger Comprehensive Cancer Center, University of North Carolina, 170 Manning Drive, CB 7305, Chapel Hill, NC 27599-7305, USA. ${ }^{3}$ Department of Medicine, Division of Hematology-Oncology, University of North Carolina, 170 Manning Drive, CB 7305, Chapel Hill, NC 27599-7305, USA.

Published: 1 April 2011

\section{References}

1. Keam B, Im SA, Lee KH, Han SW, Oh DY, Kim JH, Lee SH, Han W, Kim DW, Kim TY, Park IA, Noh DY, Heo DS, Bang YJ: Ki-67 can be used for further 
classification of triple-negative breast cancer into two subtypes with different response and prognosis. Breast Cancer Res 2011, 13:R22.

2. Perou CM, Sorlie T, Eisen MB, van de Rijn M, Jeffrey SS, Rees CA, Pollack JR, Ross DT, Johnsen H, Akslen LA, Fluge O, Pergamenschikov A, Williams C, Zhu SX, Lønning PE, Børresen-Dale AL, Brown PO, Botstein D: Molecular portraits of human breast tumours. Nature 2000, 406:747-752.

3. Prat A, Parker J, Karginova O, Fan C, Livasy C, Herschkowitz JI, He X, Perou CM: Phenotypic and molecular characterization of the claudin-low intrinsic subtype of breast cancer. Breast Cancer Res 2010, 12:R68.

4. Prat A, Perou CM: Deconstructing the molecular portraits of breast cancer. Mol Oncol 2011, 5:5-23.

5. Nielsen TO, Hsu FD, Jensen K, Cheang M, Karaca G, Hu Z, Hernandez-Boussard T, Livasy C, Cowan D, Dressler L, Akslen LA, Ragaz J, Gown AM, Gilks CB, van de Rijn M, Perou CM: Immunohistochemical and clinical characterization of the basal-like subtype of invasive breast carcinoma. Clin Cancer Res 2004, 10:5367-5374

6. Cheang M, Voduc D, Bajdik C, Leung S, McKinney S, Chia SK, Perou CM, Nielsen TO: Basal-like breast cancer defined by five biomarkers has superior prognostic value than triple-negative phenotype. Clin Cancer Res 2008, 14:1368-1376

7. Sorlie T, Tibshirani R, Parker J, Hastie T, Marron JS, Nobel A, Deng S, Johnsen H, Pesich R, Geisler S, Demeter J, Perou CM, Lønning PE, Brown PO, BørresenDale AL, Botstein D: Repeated observation of breast tumor subtypes in independent gene expression data sets. Proc Natl Acad Sci U S A 2003, 100:8418-8423.

8. Anders CK, Fan C, Parker JS, Carey LA, Blackwell KL, Klauber-DeMore N, Perou $\mathrm{CM}$ : Breast carcinomas arising at a young age: unique biology or a surrogate for aggressive intrinsic subtypes? J Clin Oncol 2011, 29:e18-e20.

9. Carey LA, Dees EC, Sawyer L, Gatti L, Moore DT, Collichio F, Ollila DW, Sartor Cl, Graham ML, Perou CM: The triple negative paradox: primary tumor chemosensitivity of breast cancer subtypes. Clin Cancer Res 2007. 13:2329-2334.

10. Liedtke C, Mazouni C, Hess KR, André F, Tordai A, Mejia JA, Symmans WF, Gonzalez-Angulo AM, Hennessy B, Green M, Cristofanilli M, Hortobagyi GN, Pusztai L: Response to neoadjuvant therapy and long-term survival in patients with triple-negative breast cancer. J Clin Oncol 2008, 26:1275-1281.

11. Anders C, Carey L: Biology, metastatic patterns, and treatment of patients with triple-negative breast cancer. Clin Breast Cancer 2009, 9(Suppl 2):S73-581.

12. Anders $C K$, Deal $A M$, Miller CR, Khorram C, Meng H, Burrows E, Livasy C,
Fritchie K, Ewend MG, Perou CM, Carey LA: The prognostic contribution of clinical breast cancer subtype, age, and race among patients with breast cancer brain metastases. Cancer 2011 [Epub ahead of print].

13. Carey L, Dees E, Sawyer L, Gatti L, Moore DT, Collichio F, Ollila DW, Sartor Cl, Graham ML, Perou CM: The triple negative paradox: primary tumor chemosensitivity of breast cancer subtypes. Clin Cancer Res 2007, 13:2329-2334.

14. Urruticoechea A, Smith I, Dowsett M: Proliferation marker Ki-67 in early breast cancer. J Clin Oncol 2005, 23:7212-7220.

15. Gonzalez-Angulo AM, Timms KM, Liu S, Liu S, Chen H, Litton JK, Potter J, Lanchbury JS, Stemke-Hale K, Hennessy BT, Arun BK, Hortobagyi GN, Do KA, Mills GB, Meric-Bernstam F: Incidence and outcome of BRCA mutations in unselected patients with triple receptor-negative breast cancer. Clin Cancer Res 2011, 17:1082-1089.

16. Foulkes WD, Stefansson IM, Chappuis PO, Bégin LR, Goffin JR, Wong N, Trudel M, Akslen LA: Germline BRCA1 mutations and a basal epithelial phenotype in breast cancer. J Natl Cancer Inst 2003, 95:1482-1485.

17. Lehmann B, Bauer J, Chen X: Transcriptome analysis of triple negative breast cancers identifies six distinct biological subgroups and reveals therapeutic strategies. In Supplement to Cancer Research 33rd Annual San Antonio Breast Cancer Symposium: 2010 December 8-12; San Antonio. San Antonio, TX: San Antonio Breast Cancer Symposium; 2010:PD01-PD07.

18. Sorlie T, Perou C, Tibshirani R, Aas T, Geisler S, Johnsen H, Hastie T, Eisen MB, van de Rijn M, Jeffrey SS, Thorsen T, Quist H, Matese JC, Brown PO, Botstein D, Eystein Lønning P, Børresen-Dale AL: Gene expression patterns of breast carcinomas distinguish tumor subclasses with clinical implications. Proc Natl Acad Sci U S A 2001, 98:10869-10874.

19. Anders CK, Winer EP, Ford JM, Dent R, Silver DP, Sledge GW, Carey LA: Poly(ADP-ribose) polymerase inhibition: targeted therapy for triplenegative breast cancer. Clin Cancer Res 2010, 16:4702-4710.

20. Fong PC, Boss DS, Yap TA, Tutt A, Wu P, Mergui-Roelvink M, Mortimer P, Swaisland H, Lau A, O'Connor MJ, Ashworth A, Carmichael J, Kaye SB, Schellens JH, de Bono JS: Inhibition of poly(ADP-ribose) polymerase in tumors from BRCA mutation carriers. N Engl J Med 2009, 361:123-134.

doi:10.1186/bcr2852

Cite this article as: Adamo B, Anders CK: Stratifying triple-negative breast cancer: which definition(s) to use? Breast Cancer Research 2011, 13:105. 